\title{
Impact of post-fire management on soil respiration, carbon and nitrogen content in a managed hemiboreal forest
}

\section{Parro, Kristi}

2019-03-01

Parro , K, Koster , K, Jogiste , K, Seglins , K, Sims , A, Stanturf , J A \& Metslaid , M 2019

, ' Impact of post-fire management on soil respiration, carbon and nitrogen content in a managed hemiboreal forest ' , Journal of Environmental Management, vol. 233 , pp.

371-377 . https://doi.org/10.1016/j.jenvman.2018.12.050

http://hdl.handle.net/10138/300663

https://doi.org/10.1016/j.jenvman.2018.12.050

submittedVersion

Downloaded from Helda, University of Helsinki institutional repository.

This is an electronic reprint of the original article.

This reprint may differ from the original in pagination and typographic detail.

Please cite the original version. 
1

Impact of post-fire management on soil respiration, carbon and nitrogen content in a managed hemiboreal forest

\section{Kristi Parro ${ }^{a}$, Kajar Köster ${ }^{b}$, Kalev Jõgiste ${ }^{a}$, Katrin Seglinš ${ }^{c}$, Allan Sims ${ }^{d}$, John A. Stanturf $^{\mathrm{a}, \mathrm{e}}$, Marek Metslaid ${ }^{\mathrm{a}, \mathrm{f}^{*}}$}

${ }^{a}$ Institute of Forestry and Rural Engineering, Estonian University of Life Sciences, Kreutzwaldi 5, 51006 Tartu, Estonia

${ }^{b}$ Faculty of Agriculture and Forestry, Institute for Atmospheric and Earth System Research / Forest Sciences, University of Helsinki, Latokartanonkaari 7, 00014 Helsinki, Finland

${ }^{c}$ Luua Forestry School, Luua, Jõgeva Parish, 49203 Jõgeva County, Estonia

${ }^{d}$ Environment Agency, Rõõmu tee 2, 50705 Tartu, Estonia

${ }^{e}$ Center for Forest Disturbance Science, US Forest Service, 320 Green Street, Athens, Georgia 30602 USA

${ }^{f}$ Norwegian Institute of Bioeconomy Research, P.O. Box 115, 1431 Ass, Norway

*Corresponding Author: Marek Metslaid, Institute of Forestry and Rural Engineering, Estonian University of Life Sciences, Kreutzwaldi 5, Tartu, Estonia, E-mail: marek.metslaid@emu.ee 


\begin{abstract}
Boreal forests are an important carbon (C) sink and fire is the main natural disturbance, directly affecting the $\mathrm{C}$-cycle via emissions from combustion of biomass and organic matter and indirectly through long-term changes in C-dynamics including soil respiration. Carbon dioxide $\left(\mathrm{CO}_{2}\right)$ emission from soil (soil respiration) is one of the largest fluxes in the global C-cycle. Recovery of vegetation, organic matter and soil respiration may be influenced by the intensity of post-fire management such as salvage logging. To study the impact of forest fire, fire and salvage, and recovery time on soil respiration and soil $\mathrm{C}$ and $\mathrm{N}$ content, we sampled two permanent research areas in north-western Estonia that were damaged by fire: Vihterpalu $\left(59^{\circ} 13^{\prime}\right.$ N $23^{\circ} 49^{\prime}$ E) in 1992 and Nõva $\left(59^{\circ} 10^{\prime} \mathrm{N} 23^{\circ} 45^{\prime} \mathrm{E}\right)$ in 2008 . Three types of sample plots were established: 1) unburned control with no harvesting (CO); 2) burned and uncleared (BU); and 3) burned and cleared (BC). Measurements were made in 2013, 21 years after wildfire in Vihterpalu and 5 years after wildfire in Nõva. Soil respiration ranged from 0.00 to $1.38 \mathrm{~g} \mathrm{CO}_{2} \mathrm{~m}^{-2} \mathrm{~h}^{-1}$. Soil respiration in the burned and cleared areas $(\mathrm{BC})$ was not reduced compared to burned and uncleared (BU) areas but the average soil respiration in unburned control areas was more than twice the value in burned areas (average soil respiration in $\mathrm{CO}$ areas was $0.34 \mathrm{CO}_{2} \mathrm{~m}^{-2} \mathrm{~h}^{-1}$, versus $0.16 \mathrm{CO}_{2} \mathrm{~m}^{-2} \mathrm{~h}^{-1}$, the average soil respiration of $\mathrm{BC}$ and $\mathrm{BU}$ combined). Recovery over 20 years was mixed; respiration was insignificantly lower on younger than older burned sites (when BC and $\mathrm{BU}$ values were combined, the average values were 0.15 vs. $0.17 \mathrm{~g} \mathrm{CO}_{2} \mathrm{~m}^{-2} \mathrm{~h}^{-1}$, respectively); soil-C was greater in the older burned plots than the younger (when $\mathrm{BC}$ and $\mathrm{BU}$ values were combined, the average values were $9.71 \mathrm{vs} .5 .99 \mathrm{~kg} \mathrm{~m}^{-2}$, respectively); but root biomass in older and recently burned areas was essentially the same (average 2.23 and $2.11 \mathrm{~kg}$ $\mathrm{m}^{-2}$, respectively); soil-N was highest on burned areas 20 years after fire. Twenty years post-fire
\end{abstract}


may be insufficient time for carbon dynamics to fully recover on these low productivity sandy sites.

Keywords: soil organic matter, carbon cycling, salvage logging

\section{Introduction}

Forest ecosystems are an important carbon (C) sink and store approximately $80 \%$ of all terrestrial aboveground C and 40-47\% of all soil organic C (Jandl et al., 2007; Jobbágy and Jackson, 2000; Wei et al., 2014). Boreal forests are an important part of the climate system since they contain about 35\% of the C (259 gigatons) bound in global forest biomes (Pan et al., 2011) although other estimates are considerably higher (as much as 1715.8 gigatons $\mathrm{C}$; Bradshaw and Warkentin, 2015). Forests sequester $\mathrm{C}$ and store it above-ground (i.e., trees) and below-ground (i.e., soil, roots), and approximately $80 \%$ to $95 \%$ of the $\mathrm{C}$ stored in boreal regions is found in forest soils and peats (Bradshaw and Warkentin, 2015; Goodale et al., 2002). In (hemi)boreal forests, nitrogen $(\mathrm{N})$ availability plays a key role in regulating the production of biomass, organic matter decomposition and $\mathrm{C}$ allocation (Palviainen et al., 2017). Therefore, $\mathrm{N}$ is a key determinant of $\mathrm{C}$ sequestration and C pools (Högberg, 2012; Hyvönen et al., 2008).

In forest ecosystems both anthropogenic (e.g., thinning, harvesting) and natural (e.g., fire, windthrow) disturbances are important influences on forest structure formation, composition and functioning (Hicke et al., 2012; Köster et al., 2009; Seidl et al., 2014). In boreal regions wildfires greatly affect forest structure and function as they cause loss of above-ground (15-35\%) and below-ground (37-70\%) biomass due to combustion (Shorohova et al., 2009). Disturbances also impact $\mathrm{C}$ dynamics by disrupting $\mathrm{C}$ sequestration and affecting $\mathrm{C}$ exchange between soil and atmosphere (Buchmann, 2000). Fire is the main natural disturbance in boreal forests and it is expected to increase in frequency as a result of climate change (Flannigan et al., 2009). Fires 
directly affect the $\mathrm{C}$-cycle via increased $\mathrm{CO}_{2}$ emissions from the combustion of biomass and indirectly through long-term changes in the C-dynamics of ecosystems including post-fire recovery of forest stands (Goulden et al., 2011; Köster et al., 2014, 2016a), and by altered chemical composition of soil organic matter (González-Pérez et al., 2004; Knicker, 2007). It has been found that forest fires considerably decrease $\mathrm{N}$ pools in biomass, while changes in soil $\mathrm{N}$ pools are small (Palviainen et al. 2017). In the organic soil layer, part of the stored $\mathrm{N}$ is lost, but in mineral soil the $\mathrm{N}$ pool usually remains mostly unchanged (Giesen et al., 2008; Nave et al., 2011; Yermakov and Rothstein, 2006).

The balance between above-ground and below-ground production of plant litter and decomposition of that material by soil microorganisms regulates soil C-pools (Köster et al., 2011, 2016b). Carbon dioxide $\left(\mathrm{CO}_{2}\right)$ emission from the soil is one of the greatest fluxes in the global C-cycle and even small changes in soil respiration may greatly impact atmospheric $\mathrm{CO}_{2}$ concentration (Schlesinger and Andrews, 2000). The notable increase in $\mathrm{CO}_{2}$ emissions from soil since the 1960s has been linked to global climate change (Buchmann, 2000). Soil respiration is affected by several factors, among these soil temperature and humidity are considered to be the most important (Karhu et al., 2014; Raich and Schlesinger, 1992), and these factors vary seasonally and throughout the growing season (Köster et al., 2016a). Altered future climate that increases air temperature and changes rainfall patterns will also affect soil temperature and water content, impacting soil microbial communities and thereby influencing soil respiration (Anderson, 2011).

The investigation of soil respiration has increased significantly in recent decades and some studies have examined the effects of disturbances (e.g. fire, windthrow) on soil respiration in forest ecosystems (Concilio et al., 2006; Hubbard et al., 2004; Köster et al., 2011, 2016a). Most studies are conducted either in nature reserves, where decomposable material was left in the area after disturbance (Köster et al., 2014, 2015, 2016b), or in managed forests where the material was removed after fire disturbance (López-Serrano et al., 2016; Poirer et al., 2014). Thus, there are few studies where post-disturbance management levels could be compared. In earlier studies 
in Vihterpalu and Nõva the impact of different post-fire management treatments on forest regeneration (Parro et al., 2015) and ground vegetation dynamics (Parro et al., 2009) was examined. The objective of the current study was to assess the impact of forest fire and time since wildfire on soil respiration and soil $\mathrm{C}$ and $\mathrm{N}$ content in scenarios where the area was or was not managed after wildfire disturbance. The factors affecting soil respiration were assessed, such as soil $\mathrm{C}$ and $\mathrm{N}$ content, the relationship between respiration and temperature, and the impacts of disturbances (fire and salvage) on soil respiration and time needed to recover.

Soil respiration is the combination of microbial and root respiration, thus in addition to temperature and moisture, the $\mathrm{C}$ available for decomposition and root biomass affects respiration levels. Disturbances such as wildfire and logging that remove plant material reduce respiration but as vegetation recovers, over time respiration increases. We hypothesized that 1) soil respiration is highest in control areas where no fire or forest management has occurred; 2) soil respiration in burned and uncleared areas where dead and live trees were left after fire is higher compared to burned and cleared areas where trees were removed after fire; 3) soil respiration is lower in recently burned areas as compared to older burned areas; and 4) soil respiration is higher with higher soil temperatures.

\section{Materials and methods}

\subsection{Study areas}

Estonia belongs to the hemiboreal vegetation zone (Ahti et al., 1968) where the average annual temperature is $+5.2^{\circ} \mathrm{C}$. The coldest month is February, with an average temperature of $-5.7^{\circ} \mathrm{C}$, and the warmest month is July, with an average temperature of $+16.4{ }^{\circ} \mathrm{C}$. The average precipitation is $550-650 \mathrm{~mm}$. This study was carried out in two permanent research areas in north-western Estonia that were damaged by fire: Vihterpalu (59 $13^{\prime} \mathrm{N} 23^{\circ} 49^{\prime}$ E) and Nõva $\left(59^{\circ} 10^{\prime} \mathrm{N} 23^{\circ} 45^{\prime} \mathrm{E}\right)$ (Figure 1). The distance between the Vihterpalu and Nõva areas is around $10 \mathrm{~km}$. The area is flat with no elevation differences. Both sites originally regenerated after 
severe stand replacing fires in 1940 (Nõva) and 1951 (Vihterpalu) and were covered with planted or sown Scots pine (Pinus sylvestris L.). Stand-replacing fires removed the vegetation layer and caused the loss of soil organic matter. The ground was covered with ash and sand was exposed in spots. Burned and cleared areas had double-disturbances: the fire damaged area was salvage logged. Fire occurred again in Vihterpalu in 1992 (severe stand replacing fire, 550 ha burned), when the forest was 52 years old, and in 2008 in Nõva (severe stand replacing fire, 800 ha burned), when the forest was 70 years old. The stands had not been thinned before the recent wildfires occurred.

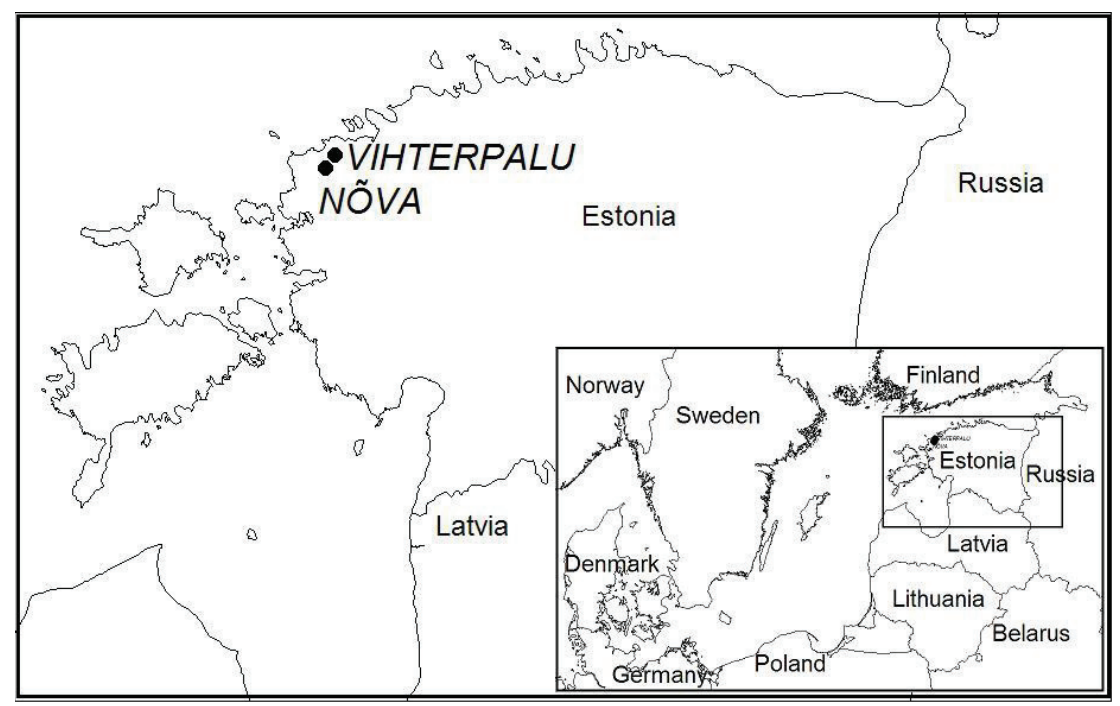

Fig. 1. Location of the permanent research areas in north-western Estonia.

The Vihterpalu and Nõva forests belong to the Vaccinium uliginosum and Calluna site types (Lõhmus, 2004), with sandy and dry soils. Productivity in these forests was low, and stands were in the lower site-quality classes. In both study areas, two sample plots $(20 \times 40 \mathrm{~m})$ were established in each of three treatment areas: 1) unburned control (CO), unburned areas where no harvesting (management) was carried out; 2) burned and uncleared (BU), burned areas without management in which both dead and live trees were left on the plots after fire; and 3) burned and cleared (BC), areas in which all dead and live trees were harvested from the plot after fire. These 
12 plots ( 6 plots in Vihterpalu, 6 plots in Nõva) were established at least $200 \mathrm{~m}$ apart for vegetation sampling (Parro et al., 2009, 2015) and sub-sampled for the current study.

\subsection{Sampling}

Within each of the 12 sample plots, soil respiration $\left(\mathrm{g} \mathrm{CO}_{2} \mathrm{~m}^{-2} \mathrm{~h}^{-1}\right)$ was measured on four permanent collars, located systematically in a line with $8 \mathrm{~m}$ separation between collars (Figure 2). Measurements were made in 2013, 21 years after wildfire at Vihterpalu and 5 years after fire disturbance at Nõva. One month before the first soil respiration measurement, a permanent plastic (polypropylene) collar was inserted into the soil at each sampling site. The lower edge of the collar was placed at $0.02 \mathrm{~m}$ depth of the soil. The collars were also sealed and stabilized on the outside with sand. Large plants (e.g. Calluna) within the collar were clipped with scissors but no plants were removed.

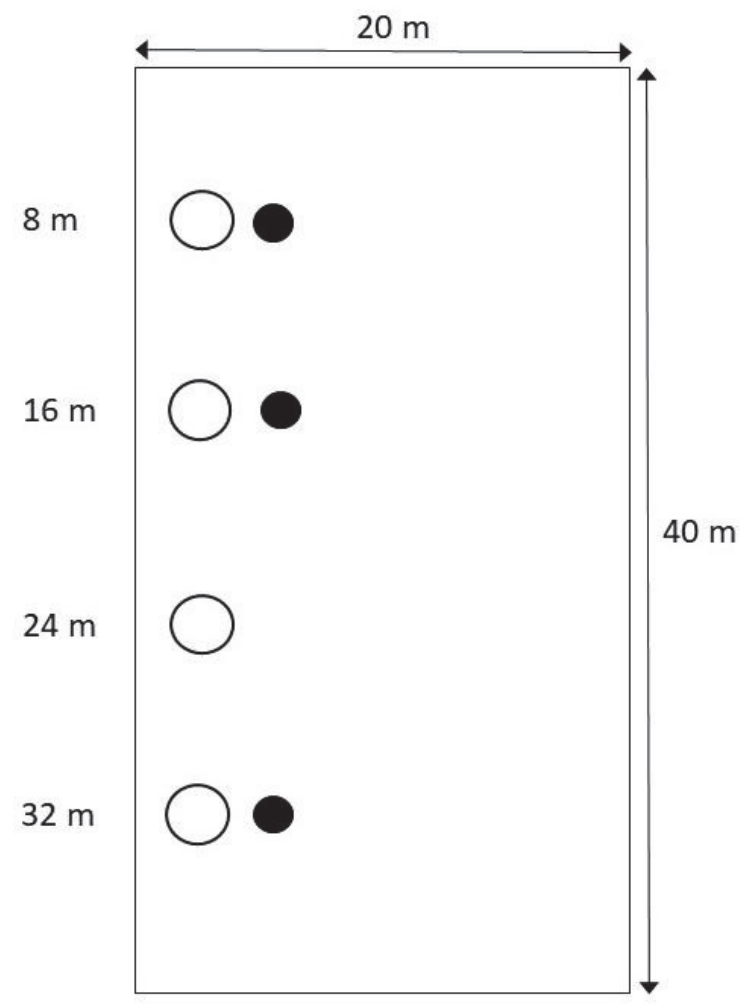


Soil respiration was measured with a portable system consisting of a CIRAS-2 infrared gas analyser attached to a closed, dynamic SRC-1 soil respiration chamber (PP-Systems, Hitchin, UK). Measurements were carried out from July to September 2013 (all together 4 measurements per collar in mid-July, beginning of August, end of August and mid-September). A closed chamber (volume of $1170 \mathrm{~cm}^{3}$ ) was placed on the plastic collar (diameter $100 \mathrm{~mm}$, height 50 $\mathrm{mm}$ ) installed on the soil. The rate of increase of the $\mathrm{CO}_{2}$ concentration inside the chamber was measured using a linear fitting and a measurement time of 120 seconds. The respiration chamber was ventilated for at least 30 seconds before a measurement to achieve stable $\mathrm{CO}_{2}$ concentration. Respiration measurements were not carried out during rain events to keep measurement conditions as stable as possible. During the measurements in July weather was mostly sunny (one day was a little cloudy), air temperatures ranged between 19 to $22{ }^{\circ} \mathrm{C}$, with light breezes. At the beginning of August weather was mostly sunny (one day was cloudy), air temperatures ranged between 18 to $22{ }^{\circ} \mathrm{C}$, with light breezes (one day was windy). At the end of August weather was mostly sunny and a partly cloudy, air temperatures ranged between 17 to $21{ }^{\circ} \mathrm{C}$, with light breezes. In September weather was mostly sunny (one day was half cloudy), air temperatures ranged between 17 to $18^{\circ} \mathrm{C}$, with light breezes (one day was windy). In total, 181 respiration measurements were made. Soil temperature at $5 \mathrm{~cm}$ depth was measured adjacent to the first and fourth collar at the time of respiration measurements with a temperature sensor STP1 (PP-Systems, Hitchin, UK) connected to the portable soil-respiration system, resulting in 92 soil temperature measurements.

In each sample plot, soil samples within $0.5 \mathrm{~m}$ of the soil respiration collars were taken to estimate soil $\mathrm{C}\left(\mathrm{kg} \mathrm{m}^{-2}\right)$ and $\mathrm{N}\left(\mathrm{kg} \mathrm{m}^{-2}\right)$ content. One soil core was taken next to three respiration collars at the 1st, 2nd, and 4th positions (total of 36 cores) (Figure 2). The soil cores measured 50 $\mathrm{mm}$ in diameter and $500 \mathrm{~mm}$ in length; they were transported to the laboratory and stored at -18 ${ }^{\circ} \mathrm{C}$. In the laboratory, soil cores were divided according to morphological horizons. The thickness of each horizon was measured to determine volume, sieved with a $2 \mathrm{~mm}$ sieve and 
roots removed, then dried at $100{ }^{\circ} \mathrm{C}$ and weighed to calculate bulk density of each horizon. Roots were dried at $60{ }^{\circ} \mathrm{C}$ and weighed for biomass.

Soil was classified as a gleyic podzol (IUSS Working Group WRB, 2015.), with loamy sand. Its profile $(\mathrm{O}-\mathrm{E}-\mathrm{BHF}-\mathrm{BCg}-\mathrm{Cg})$ consists of the organic $(\mathrm{O})$ horizon $(2-6 \mathrm{~cm})$, discontinuous bleached sandy podzolic (E) horizon of varying thickness, iron-illuvial loamy sand (BHF) horizon, and a gradual transition towards an unevenly colored (from grey to yellowish brown color) sandy parent material (Köster et al., 2016a).

Soil $\mathrm{C}$ and $\mathrm{N}$ content were determined with an elemental analyzer (varioMAX $\mathrm{CN}$ Elementaranalysator, Elementar Analysensysteme GmbH, Hanau, Germany).

\subsection{Statistical analysis}

Statistical analyses were conducted using R (R Core Team, 2017). Data were checked for normality with the Shapiro-Wilks test. Because the respiration data were not normally distributed, a non-parametric Mann-Whitney-Wilcoxon test (also known as Mann-Whitney U test) was used to analyse differences between groups. Means, standard deviations and standard errors were calculated for soil respiration and temperature for each sample plot (6 plots at each location, 2 for each treatment at each location). All calculations and statistical analyses used the sample plot as the experimental unit and significance level of $\alpha=0.05$.

\section{Results}

\subsection{Soil respiration}

Average soil respiration values during the measurement period (from July to September 2013) across all treatments at Vihterpalu (1992 fire) varied from 0.00 to $1.38 \mathrm{~g} \mathrm{CO}_{2} \mathrm{~m}^{-2} \mathrm{~h}^{-1}$ and at Nõva 
(2008 fire) from 0.00 to $0.94 \mathrm{~g} \mathrm{CO}_{2} \mathrm{~m}^{-2} \mathrm{~h}^{-1}$ (Table 1). Average soil respiration was greatest in the beginning of August $\left(0.52 \mathrm{~g} \mathrm{CO}_{2} \mathrm{~m}^{-2} \mathrm{~h}^{-1}\right)$ and lowest in July $\left(0.09 \mathrm{~g} \mathrm{CO}_{2} \mathrm{~m}^{-2} \mathrm{~h}^{-1}\right)$.

Table 1. Soil respiration at two sites measured four times from July to September 2013 on three treatments: control $(\mathrm{CO})$, burned and cleared $(\mathrm{BC})$, and burned but uncleared $(\mathrm{BU})$. Data are averages of two plots per treatment, four respiration measurements per plot on each date $(n=8)$.

\begin{tabular}{|c|c|c|c|c|c|c|}
\hline Year of fire & \multicolumn{3}{|c|}{1992 (Vihterpalu) } & \multicolumn{3}{|c|}{2008 (Nõva) } \\
\hline Treatment & $\mathrm{CO}$ & $\mathrm{BC}$ & $\mathrm{BU}$ & $\mathrm{CO}$ & $\mathrm{BC}$ & $\mathrm{BU}$ \\
\hline Month & \multicolumn{6}{|c|}{ July } \\
\hline Minimum & 0.00 & 0.08 & 0.03 & 0.00 & 0.06 & 0.03 \\
\hline Maximum & 0.43 & 0.18 & 0.22 & 0.38 & 0.13 & 0.28 \\
\hline Average & 0.23 & 0.13 & 0.13 & 0.14 & 0.09 & 0.10 \\
\hline Month & \multicolumn{6}{|c|}{ August_1 } \\
\hline Minimum & 0.07 & 0.07 & 0.04 & 0.22 & 0.15 & 0.07 \\
\hline Maximum & 1.38 & 0.35 & 0.28 & 0.69 & 0.21 & 0.47 \\
\hline Average & 0.52 & 0.17 & 0.17 & 0.43 & 0.18 & 0.19 \\
\hline Month & \multicolumn{6}{|c|}{ August 2} \\
\hline Minimum & - & 0.03 & 0.02 & 0.09 & 0.05 & 0.03 \\
\hline Maximum & - & 0.20 & 0.41 & 0.84 & 0.25 & 0.52 \\
\hline Average & - & 0.11 & 0.18 & 0.42 & 0.13 & 0.14 \\
\hline Month & \multicolumn{6}{|c|}{ September } \\
\hline Minimum & 0.03 & 0.07 & 0.01 & 0.02 & 0.03 & 0.03 \\
\hline Maximum & 0.45 & 0.76 & 0.35 & 0.94 & 0.29 & 0.62 \\
\hline Average & 0.24 & 0.33 & 0.13 & 0.39 & 0.14 & 0.26 \\
\hline
\end{tabular}

Note: the data for August_2, CO, 1992 (Vihterpalu) is missing due to technical obstacles. 


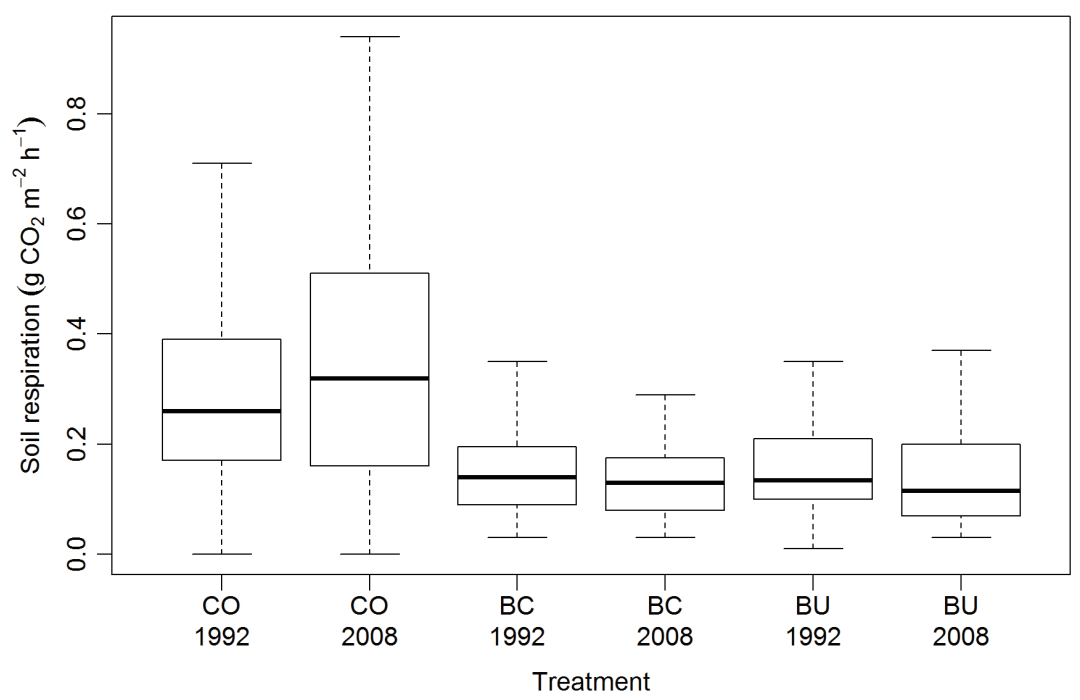

Fig. 3. Effect of treatments on soil respiration on two sites (1992=Vihterpalu, 2008=Nõva) with different times since wildfire. Values of soil respiration $\left(\mathrm{g} \mathrm{CO}_{2} \mathrm{~m}^{-2} \mathrm{~h}^{-1}\right)$ are averages of measurements on two plots, each sampled on four dates in 2013. Control areas (CO) were unburned and unmanaged; burned and cleared (BC) were harvested after fire; and burned and uncleared areas (BU) had all dead and live trees left on the area after fire.

Soil respiration was higher in $\mathrm{CO}$ areas than in $\mathrm{BC}$ and $\mathrm{BU}$ areas $(p<0.0001)$ (Table 1; Figure 3). The average soil respiration was $0.34 \mathrm{~g} \mathrm{CO}_{2} \mathrm{~m}^{-2} \mathrm{~h}^{-1}$ in $\mathrm{CO}$ areas (Vihterpalu and Nõva combined), which was $0.18 \mathrm{~g} \mathrm{CO}_{2} \mathrm{~m}^{-2} \mathrm{~h}^{-1}$ higher than on $\mathrm{BC}$ and $\mathrm{BU}$ areas (Vihterpalu and Nõva combined), where respiration averaged $0.16 \mathrm{~g} \mathrm{CO}_{2} \mathrm{~m}^{-2} \mathrm{~h}^{-1}$. The $\mathrm{BC}$ and $\mathrm{BU}$ treatments were not significantly different from each other $(p=0.851)$.

Comparison of two sites with differing times since wildfire showed that soil respiration was lower (on average $0.15 \mathrm{~g} \mathrm{CO}_{2} \mathrm{~m}^{-2} \mathrm{~h}^{-1}$, from both $\mathrm{BC}$ and $\mathrm{BU}$ areas) on areas where fire had occurred more recently (2008 fire in Nõva) than on areas burned in 1992 in Vihterpalu (on average $0.17 \mathrm{~g} \mathrm{CO}_{2} \mathrm{~m}^{-2} \mathrm{~h}^{-1}$, from both $\mathrm{BC}$ and $\mathrm{BU}$ areas), but the difference was not significant $(p=0.105)$ (Table 1). At Vihterpalu (1992 wildfire) the average $\mathrm{CO}_{2}$ release on the control areas (CO) was $0.33 \mathrm{~g} \mathrm{~m}^{-2} \mathrm{~h}^{-1}$, on burned and cleared areas (BC) $0.19 \mathrm{~g} \mathrm{~m}^{-2} \mathrm{~h}^{-1}$, and on burned and uncleared areas (BU) soil respiration averaged $0.15 \mathrm{~g} \mathrm{CO}_{2} \mathrm{~m}^{-2} \mathrm{~h}^{-1}$. Despite the different intervals 
since wildfire, the average soil respiration at Nõva (2008 wildfire) was almost the same as Vihterpalu $\left(\mathrm{CO}=0.35 \mathrm{~g} \mathrm{CO}_{2} \mathrm{~m}^{-2} \mathrm{~h}^{-1}, \mathrm{BC}=0.14 \mathrm{~g} \mathrm{CO}_{2} \mathrm{~m}^{-2} \mathrm{~h}^{-1}\right.$, and $\left.\mathrm{BU}=0.17 \mathrm{~g} \mathrm{CO}_{2} \mathrm{~m}^{-2} \mathrm{~h}^{-1}\right)$.

\subsection{Soil temperature}

During the measurement period soil temperatures varied from 9.5 to $23.5{ }^{\circ} \mathrm{C}$, with the highest temperatures at both sites in early August and lowest temperatures in September. The average temperature for all measurements was $15.28{ }^{\circ} \mathrm{C}$. Average temperatures for treatments were: $14.01{ }^{\circ} \mathrm{C}$ on $\mathrm{CO}$ areas, $16.63{ }^{\circ} \mathrm{C}$ on $\mathrm{BC}$ areas and $15.06^{\circ} \mathrm{C}$ on BU areas. However, there was no significant relationship between soil respiration and soil temperature (Figure $4 ; p=0.068$ ).
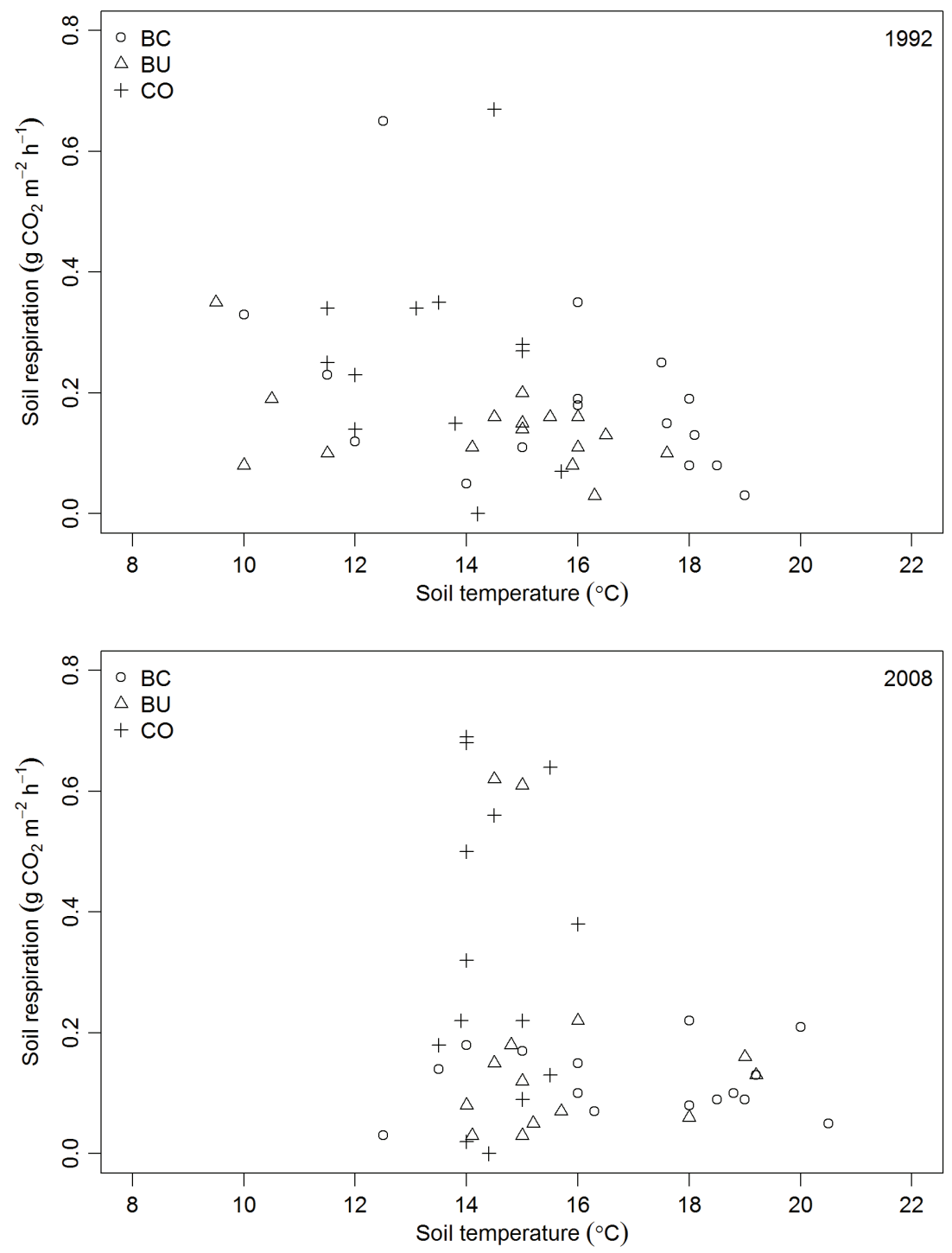
Fig. 4. Soil temperature and respiration at Vihterpalu (1992) and Nõva (2008), indicating no significant relationship. Treatments are $\mathrm{CO}=$ control, $\mathrm{BC}=$ burned and cleared, and $\mathrm{BU}=$ burned and uncleared.

\subsection{Soil thickness and root mass}

Top soil layer was thickest in $\mathrm{CO}$ areas $(6.0 \mathrm{~cm}$ in average, from both Vihterpalu and Nõva areas), followed by $\mathrm{BC}$ areas, $\mathrm{BU}$ areas, 2.85 and $2.3 \mathrm{~cm}$, respectively (combined values from Vihterpalu and Nõva areas) (Table 2). In 1992 areas the top soil layer thickness in CO areas was on average $6.4 \mathrm{~cm}$, followed by $\mathrm{BC}$ areas that averaged $3.2 \mathrm{~cm}$ and $\mathrm{BU}$ areas that averaged 2.3 $\mathrm{cm}$. In 2008 areas the respective top soil layer thickness values for CO, BC and BU areas were $5.6 \mathrm{~cm}, 2.5 \mathrm{~cm}$ and $2.3 \mathrm{~cm}$, respectively.

Table 2. Average soil horizon thicknesses $(\mathrm{cm})$ from each of two sites, by treatment $(\mathrm{CO}=$ control, $\mathrm{BU}=$ burned and uncleared, $\mathrm{BC}=$ burned and cleared $)$.

\begin{tabular}{lccc|lccc}
\hline \multicolumn{3}{c}{} & \multicolumn{5}{c}{ Nõva } \\
\hline \multicolumn{3}{c}{ Treatment } & \multicolumn{4}{c}{ Treatment } \\
\hline Horizon & $\mathrm{CO}$ & $\mathrm{BU}$ & $\mathrm{BC}$ & Horizon & $\mathrm{CO}$ & $\mathrm{BU}$ & $\mathrm{BC}$ \\
\hline $\mathrm{O}$ & $6.4 \pm 0.4$ & $2.3 \pm 0.7$ & $3.2 \pm 0.7$ & $\mathrm{O}$ & $5.6 \pm 1.0$ & $2.3 \pm 0.4$ & $2.5 \pm 1.0$ \\
$\mathrm{E}$ & $7.8 \pm 0.3$ & $6.8 \pm 0.6$ & $8.3 \pm 0.4$ & $\mathrm{E}$ & $9.9 \pm 0.6$ & $7.6 \pm 0.8$ & $7.8 \pm 0.5$ \\
$\mathrm{BHF}$ & $10.8 \pm 0.6$ & $9.8 \pm 0.9$ & $11.1 \pm 0.4$ & $\mathrm{BHF}$ & $11.9 \pm 0.6$ & $9.6 \pm 0.6$ & $9.8 \pm 0.5$ \\
$\mathrm{BCg}$ & $12.1 \pm 0.5$ & $10.8 \pm 1.9$ & $10.5 \pm 1.9$ & $\mathrm{BCg}$ & $11.1 \pm 1.4$ & $10.8 \pm 1.6$ & $11.0 \pm 0.9$ \\
$\mathrm{Cg}$ & $17.1 \pm 2.5$ & $12.1 \pm 3.9$ & $10.9 \pm 2.2$ & $\mathrm{Cg}$ & $11.7 \pm 1.9$ & $13.3 \pm 0.9$ & $18.2 \pm 4.5$ \\
\hline
\end{tabular}

Average root dry mass was highest in control areas $\left(3.70 \mathrm{~kg} \mathrm{~m}^{-2}\right)$, followed by burned and uncleared areas $\left(2.31 \mathrm{~kg} \mathrm{~m}^{-2}\right)$ and burned and cleared areas $\left(1.92 \mathrm{~kg} \mathrm{~m}^{-2}\right)$. Root dry mass from control areas was significantly different from fire-disturbed areas $(p=0.020)$. Dry mass of roots was higher in the older burned area (Vihterpalu 1992) $2.23 \mathrm{~kg} \mathrm{~m}^{-2}$, than in the more recent burned area (Nõva 2008), $2.11 \mathrm{~kg} \mathrm{~m}^{-2}$.

\subsection{Soil carbon and nitrogen content}




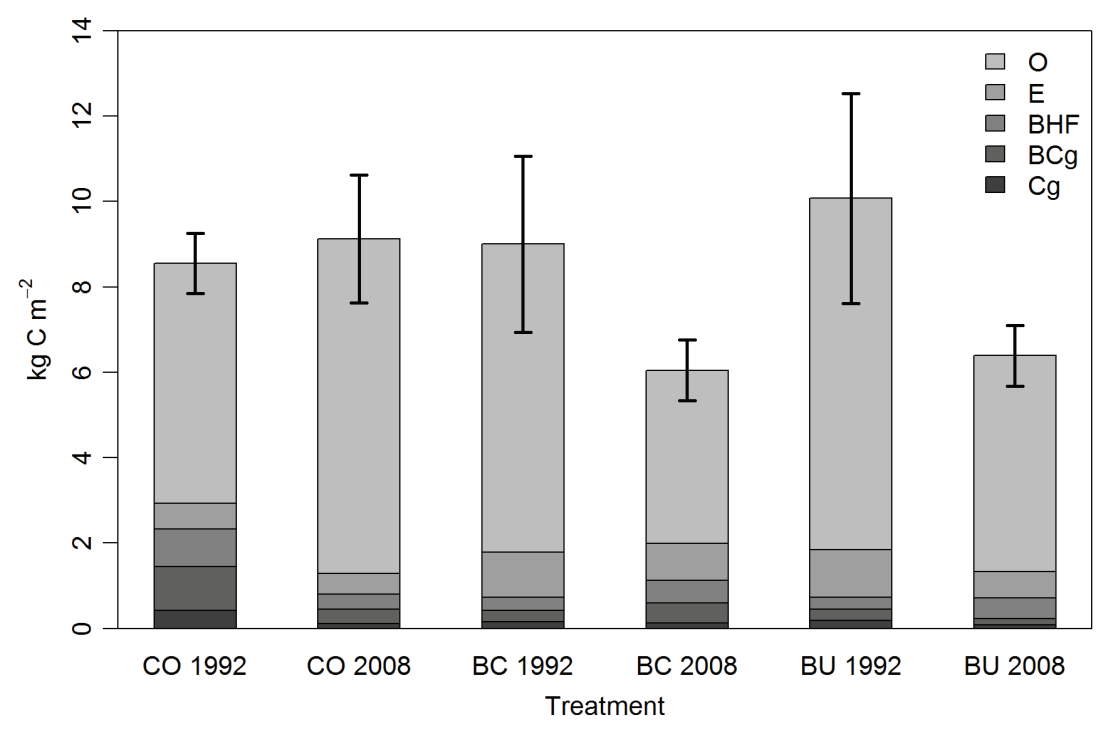

Fig. 5. Average carbon content in forest soil in Vihterpalu (fire in 1992) and Nõva (fire in 2008) study areas $\left(\mathrm{kg} \mathrm{m}^{-2}\right.$ and standard deviation). Control areas $(\mathrm{CO})$ - unburned and no management activities carried out; (b) burned and cleared (BC) - harvested after fire; and (c) burned and uncleared areas $(\mathrm{BU})$ - dead and live trees were left onsite after fire. Soil horizons are $\mathrm{O}=$ litter and humus combined, $\mathrm{E}=$ =eluvial spodic horizon, $\mathrm{BHF}=$ iron-illuvial loamy sand, $\mathrm{BCg}=$ illuvial sandy horizon, and $\mathrm{Cg}=$ sandy parent material. 
Soil nitrogen $(\mathrm{N})$ stocks averaged $0.334 \mathrm{~kg} \mathrm{~m}^{-2}$ in $\mathrm{CO}$ areas, $0.303 \mathrm{~kg} \mathrm{~m}^{-2}$ in BU areas and 0.297 $\mathrm{kg} \mathrm{m}^{-2}$ in $\mathrm{BC}$ areas (Figure 6). Similar to soil C stocks, soil N stocks were significantly lower ( $p$ $<0.05$ ) in the recently burned site (Nõva 2008) BC and BU areas compared to other areas (Figure 6). Average $\mathrm{N}$ content in the organic (O) horizons across all treatments was $0.239 \mathrm{~kg} \mathrm{~m}^{-2}$, which was higher than in mineral soil horizons $\left(0.018 \mathrm{~kg} \mathrm{~m}^{-2}\right)$. Soil $\mathrm{N}$ recovered in a similar pattern to soil $\mathrm{C}$ in that the control plot $\mathrm{N}$ content was similar $\left(0.371\right.$ and $0.297 \mathrm{~kg} \mathrm{~m}^{-2}$ in Vihterpalu and Nõva, respectively) while soil $\mathrm{N}$ in managed plots of the older burned site recovered to higher levels ( 0.447 and $0.399, \mathrm{BC}$ and $\mathrm{BU}$ respectively) as compared to the more recently burned site $(0.197$ and $0.239, \mathrm{BC}$ and BU respectively). Nevertheless, unlike soil C, soil respiration and soil $\mathrm{N}$ content were not significantly correlated $(p=0.139)$.

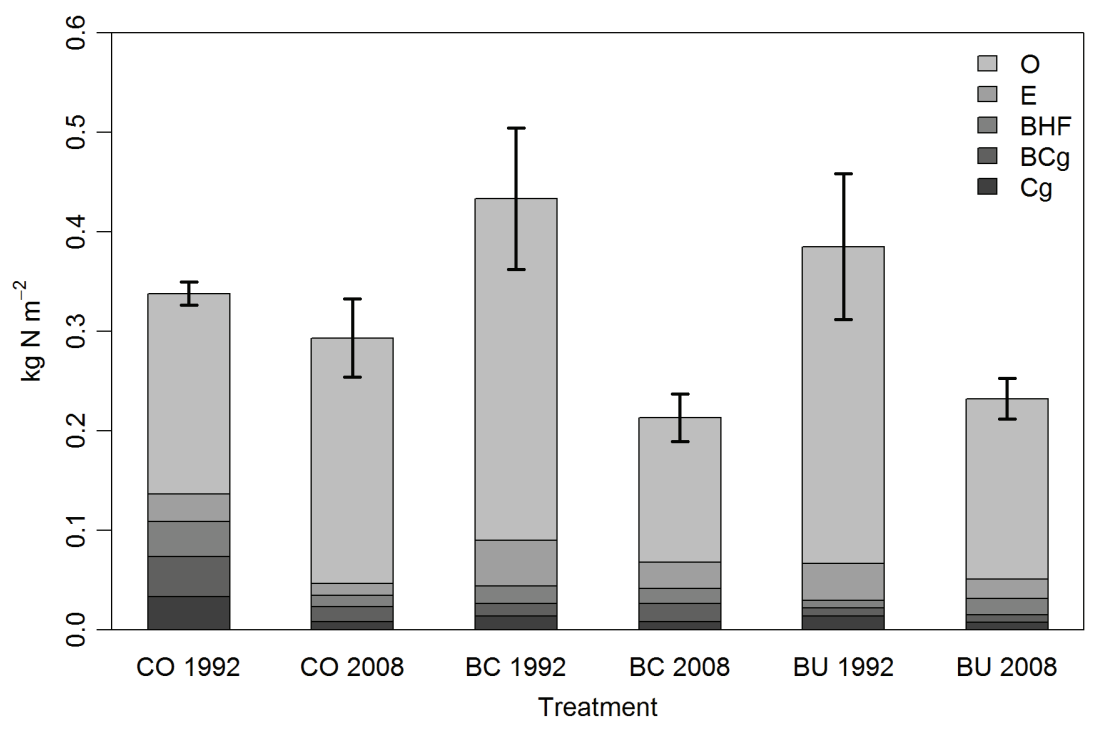

Fig. 6. Average nitrogen content in forest soil in Vihterpalu (fire in 1992) and Nõva (fire in 2008) study areas $\left(\mathrm{kg} \mathrm{m}^{-2}\right)$ and standard deviation. Control areas (CO) - unburned and no management activities carried out; (b) burned and cleared (BC) - harvested after fire; and (c) burned and uncleared areas (BU) - dead and live trees were left onsite after fire. Soil horizons are $\mathrm{O}=$ litter and humus combined, $\mathrm{E}=$ eluvial spodic horizon, $\mathrm{BHF}=$ iron-illuvial loamy sand, $\mathrm{BCg}=$ illuvial sandy horizon, and $\mathrm{Cg}=$ sandy parent material.

Soil $\mathrm{C} / \mathrm{N}$ ratios mostly varied by horizons. The highest average $\mathrm{C} / \mathrm{N}$ ratios were found in the $\mathrm{E}$ horizons: 39.3 in control areas, 33.2 in burned and cleared areas and 33.1 in burned and 
uncleared areas. Average $\mathrm{E}$ horizon $\mathrm{C} / \mathrm{N}$ ratios in control areas were significantly different from fire-disturbed areas $(p=0.012)$. High $\mathrm{C} / \mathrm{N}$ ratios were observed also in BHF horizons where the highest values were observed in control areas (36.5) followed by burned and uncleared areas (30.3) and burned and cleared areas (29.8). The average $\mathrm{C} / \mathrm{N}$ ratios in $\mathrm{O}$ horizon were 29.4 in control areas, 25.9 in burned and uncleared areas and 24.2 in burned and cleared areas. The lowest $\mathrm{C} / \mathrm{N}$ ratios were observed in deeper horizons where the values stayed below 20 .

\section{Discussion}

Soil respiration values found in this study ranged from 0.00 to $1.38 \mathrm{CO}_{2} \mathrm{~m}^{-2} \mathrm{~h}^{-1}$ and were similar to other published work in boreal forests (Concilio et al., 2006; Czimczik et al., 2006; Köster et al., 2011). Fire, especially wildfire, has been found to negatively affect soil respiration (Czimczik et al., 2006; Sullivan et al., 2011), which was supported by results of this study. The highest soil respiration values were recorded in control (CO) areas that were not affected by forest fires, which was more than twice the value of respiration in burned areas (average soil respiration in $\mathrm{CO}$ areas was $0.37 \mathrm{CO}_{2} \mathrm{~m}^{-2} \mathrm{~h}^{-1}$, versus the average of the $\mathrm{BC}$ and $\mathrm{BU}$ areas combined, which was $0.16 \mathrm{CO}_{2} \mathrm{~m}^{-2} \mathrm{~h}^{-1}$ ). Fire destroys the litter and upper organic layer (F-horizon) and the underlying humus layer (H-horizon) is severely damaged. It is in these soil horizons, however, that most soil respiration takes place in the form of decomposition processes and root respiration. Thus, fires significantly affect soil respiration by removing carbonaceous material and reducing root mass, thereby affecting post-fire recovery of burnt areas.

Post-fire management, including the removal of dead and live trees, greatly influences the physical and chemical composition of soil (Luo and Zhou, 2006). The effect of harvesting on soil respiration depends on several factors, such as cutting method (Luo and Zhou, 2006), tree species composition (broadleaf litter decomposes faster than coniferous litter; Berg and Laskowski, 2006), stand age (Concilio et al., 2006) and climatic conditions (Luo and Zhou, 2006). Temperature has a significant impact on $\mathrm{CO}_{2}$ fluxes (Buchmann, 2000; Köster et al., 2011) but studies of the effects of clear-cutting have found opposing results. Wang et al. (1999) 
and Striegl and Wickland (1998) found that clear-cutting did not affect soil respiration. However, Lytle and Cronan (1998) found decreased soil respiration after harvesting. The current study examined whether removing or leaving dead and live trees after burning affected soil respiration differently. The expectation was that soil respiration would be higher in burned and uncleared (BU) areas than on burned and cleared areas $(\mathrm{BC})$ but our results failed to confirm this hypothesis. A possible explanation is that removing the trees raised the soil temperature thus improving conditions for vegetation growth and increasing the amount of litter produced. More litter would in turn lead to more decomposition and increase the release of $\mathrm{CO}_{2}$ from the soil.

No direct relationship was found between respiration and soil temperature from July to September. The lowest average soil temperature was measured in burned and uncleared (BU) areas $\left(9.5^{\circ} \mathrm{C}\right)$ and the highest in burned and cleared $(\mathrm{BC})$ areas $\left(20.5^{\circ} \mathrm{C}\right)$. In spring and autumn soil temperature in burned and harvested areas rises faster than in unburned forests. In areas where tree crowns are damaged or missing, soils warm quicker than under an intact canopy (Certini, 2005) because solar radiation reaches the ground unimpeded (Griffiths and Swanson, 2001). In addition, post-fire soil is darker and therefore actively absorbs sunlight.

It was hypothesized that recently burned areas (wildfire in 2008) would have lower soil respiration values than areas burned more than 20 years ago (wildfire in 1992). The results confirmed this expectation $\left(0.15 \mathrm{~g} \mathrm{CO}_{2} \mathrm{~m}^{-2} \mathrm{~h}^{-1}\right.$ versus $0.17 \mathrm{~g} \mathrm{CO}_{2} \mathrm{~m}^{-2} \mathrm{~h}^{-1}$, respectively). The difference was not statistically significant, however, even though all the preconditions were there for soil respiration to be higher in the 1992 fire areas, including a thick litter and F-horizon and higher soil $\mathrm{C}$ content. It can be argued that in our study areas, dominated by relatively infertile sandy soils, 20 years is too short a period for the soil $\mathrm{C}$ and soil respiration to recover. It has been found that it may take 3-10 years in boreal forests for post-fire soil $\mathrm{CO}_{2}$ efflux to recover (Köster et al., 2015), and the recovery is affected by vegetation type, vegetation coverage and post-fire biomass recovery (Raich and Tufekcioglu, 2000). The pine forests in our study areas were growing on sandy soils where the soil organic layer was thin and the stand replacing fire 
consumed almost all the soil organic layer making it difficult for trees to regenerate and ground vegetation to establish on pure sand (Köster et al., 2016a).

The amount of $\mathrm{C}$ available for decomposition affects soil respiration and soil respiration increases with the addition of organic C into soil (Schlesinger and Andrews, 2000). The C content was higher in the biologically most active $\mathrm{O}$ horizon. Comparison of different fire years showed that the $\mathrm{C}$ content was substantially higher in areas that burned several decades ago (fire in year 1992) compared to recently burned areas (fire in year 2008). The relationship between the increase of C content and time since fire was described by Johnson and Curtis (2001) as the soil $\mathrm{C}$ content starting to increase ten years after a fire due to the thickening of the litter and organic layers. In addition, in our study the soil respiration was higher over the growing season in areas where the soil $\mathrm{C}$ concentration was higher, for example in control $(\mathrm{CO})$ areas soil respiration values were two times higher than fire areas.

Higher soil N content increases C sequestration (De Vries and Posch, 2011). N content was highest in the litter and F-horizon but we found no relationship between the soil $\mathrm{N}$ content and soil respiration. Curiously, the $\mathrm{N}$ content in the mineral soil horizons of the 1992 burned plots was greater than the control plots, something that has been observed under prescribed burning in Spodosols in Florida, USA (personal observation, J. Stanturf). The unburned control areas had higher $\mathrm{C} / \mathrm{N}$ ratios than both burned areas. The $\mathrm{C} / \mathrm{N}$ ratios of the $\mathrm{O}, \mathrm{E}$ and $\mathrm{BHF}$ horizons of control areas were greater than in the burned classes, indicating that a small amount of $\mathrm{C}$ was lost and/or $\mathrm{N}$ was gained, potentially through leaching of unburned forest floor material. Similar to the current study, Yermakov and Rothstein (2006) showed a decrease in $\mathrm{C} / \mathrm{N}$ ratios for both forest floor and upper mineral soils in recent fires when compared with older ( 72 years after fire) sites.

The increase in average $\mathrm{N}$ content after the 1992 fire might have been the result of increased decomposition of vegetation. In 2013, when measurements were carried out, 21 years had passed 
since the fire in 1992. There had been vigorous vegetation growth after the fire (Parro et al. 2015); competition and change in soil nutrients affected the young deciduous trees that started to die about 15 years after fire.

Root respiration forms a large part of soil respiration (Widén and Majdi, 2001). Recovery of root biomass, and thereby root respiration, after fire and logging disturbances may follow two pathways. Firstly, vegetation recovers over time in both above-ground and below-ground biomass. Secondly, soil organic matter content increases, which improves soil structure, making it easier for roots to penetrate through soil. For example, Saha et al. (2010) reported that belowground biomass was increasing remarkably 25 years after the fire compared to areas where fire had occurred three years ago. In our study the amount of root dry mass was highest in control (CO) areas and smallest in burned and cleared (BC) areas, which can be explained by the doubledisturbance effect. Older burned areas had slightly higher (average $2.23 \mathrm{~kg} \mathrm{~m}^{-2}$ ) root biomass than recently burned areas (average $2.11 \mathrm{~kg} \mathrm{~m}^{-2}$ ). Control (CO) areas had the highest root biomass, the thickest litter and F-horizon, and the highest soil respiration.

\section{Conclusion}

Respiration was significantly higher on control plots than burned plots. No difference in respiration rates, however, was detected on burned and cleared plots compared to burned and uncleared plots; possibly the fire efficiently removed the surface organic layers and understory vegetation, so that combined with spatial variability, no difference could be detected. Alternatively, removing the remaining overstory trees in the cleared plots increased light to the soil surface and promoted sufficient new vegetation to offset what was removed. An increase in respiration with higher soil temperatures would have supported this explanation but no direct relationship between temperature and respiration was found. 
Respiration was lower on younger than older burned sites $\left(0.15\right.$ vs. $\left.0.17 \mathrm{~g} \mathrm{CO}_{2} \mathrm{~m}^{-2} \mathrm{~h}^{-1}\right)$ but the difference was not significant. This was puzzling since the $\mathrm{C}$ available for decomposition was greater in the older burned plots than the younger (9.71 vs. $5.99 \mathrm{~kg} \mathrm{~m}^{-2}$, respectively) and soil C content and respiration were significantly correlated. Conversely, root biomass in older and recently burned areas was essentially the same (average 2.23 and $2.11 \mathrm{~kg} \mathrm{~m}^{-2}$, respectively) so that a difference in root respiration, which forms a large part of soil respiration, was unlikely to account for the lack of temporal difference in soil respiration. We suspect that the sandy and relatively infertile nature of these sites accounts for the apparent lag in recovery of soil respiration; 20 years was insufficient time for recovery of soil respiration.

\section{Acknowledgements}

This study was supported by the Environmental Investment Centre, by the Institutional Research Funding IUT21-4 of the Estonian Ministry of Education and Research, by the Estonian Research Council grant PUT (PUT715), by the project of the Estonian University of Life Sciences P180024MIME, and by the Academy of Finland projects no. 294600 and 307222.

\section{References}

Ahti, T., Hämet-Ahti, L., Jalas, J., 1968. Vegetation zones and their sections in northwestern Europe. Ann. Bot. Fenn. 5, 169-211.

Anderson, O.R., 2011. Soil respiration, climate change and the role of microbial communities. Protist 162, 679-690. DOI: 10.1016/j.protis.2011.04.001

Berg, B., Laskowski, R., 2006. Litter decomposition: a guide to carbon and nutrient turnover. Advances in Ecological Research 38. Elsevier Academic Press.

Bradshaw, C.J.A., Warkentin, I.G., 2015. Global estimates of boreal forest carbon stocks and flux. Global Planet. Change 128, 24-30. DOI: 10.1016/j.gloplacha.2015.02.004 
Buchmann, N., 2000. Biotic and abiotic factors controlling soil respiration rates in Picea abies stands. Soil Biol. Biochem. 32, 1625-1635. DOI: 10.1016/S0038-0717(00)00077-8

Certini, G., 2005. Effects of fire on properties of forest soils: a review. Oecologia 143, 1-10. DOI: $10.1007 / \mathrm{s} 00442-004-1788-8$

Concilio, A., Ma, S., Ryu, S.-R., North, M., Chen, J., 2006. Soil respiration response to experimental disturbances over 3 years. Forest Ecol. Manage. 228, 82-90. DOI: $10.1016 /$ j.foreco.2006.02.029

Czimczik, C.I., Trumbore, S.E., Carbone, M.S., Winston, G.C., 2006. Changing sources of soil respiration with time since fire in a boreal forest. Glob. Change Biol. 12, 957-971. DOI: $10.1111 / \mathrm{j} .1365-2486.2006 .01107 . x$

De Vries, W., Posch, M., 2011. Modelling the impact of nitrogen deposition, climate change and nutrient limitations on tree carbon sequestration in Europe for the period 1900-2050. Environ. Pollut. 159, 2289-2299. DOI: 10.1016/j.envpol.2010.11.023

Flannigan, M., Stocks, B., Turetsky, M., Wotton, M., 2009. Impacts of climate change on fire activity and fire management in the circumboreal forest. Glob. Change Biol. 15, 549-560. DOI: $10.1111 / \mathrm{j} .1365-2486.2008 .01660 . x$

Giesen, T.W., Perakis, S.S., Cromack, K. Jr., 2008. Four centuries of soil carbon and nitrogen change after stand-replacing fire in a forest landscape in the western Cascade Range of Oregon. Can. J. For. Res. 38, 2455-2464. DOI: 10.1139/X08-092

González-Pérez, J.A., González-Vila, F.J., Almendros, G., Knicker, H., 2004. The effect of fire on soil organic matter-a review. Environ. Intl. 30, 855-870. DOI: 10.1016/j.envint.2004.02.003

Goodale, C.L., Apps, M.J., Birdsey, R.A., Field, C.B., Heath, L.S., Houghton, R.A., Jenkins, J.C., Kohlmaier, G.H., Kurz, W., Liu, S., Nabuurs, G.-J., Nilsson, S., Shvidenko, A.Z., 2002. Forest carbon sinks in the Northern Hemisphere. Ecol. Appl. 12, 891-899. DOI: 10.1890/10510761(2002)012[0891:FCSITN]2.0.CO;2 
Goulden, M.L., McMillan, A.M.S., Winston, G.C., Rocha, A.V., Manies, K.L., Harden, J.W., Bond-Lamberty, B.P., 2011. Patterns of NPP, GPP, respiration, and NEP during boreal forest succession. Glob. Change Biol. 17, 855-871. DOI: 10.1111/j.1365-2486.2010.02274.x

Griffiths, R.P., Swanson, A.K., 2001. Forest soil characteristics in a chronosequence of harvested Douglas-fir forests. Can. J. For. Res. 31, 1871-1879. DOI: 10.1139/x01-126

Hicke, J.A., Allen, C.D., Desai, A.R., Dietze, M.C., Hall, R. J., Kashian, D.M., Moore, D., Raffa, K.F., Sturrock, R.N., Vogelmann, J., 2012. Effects of biotic disturbances on forest carbon cycling in the United States and Canada. Glob. Change Biol. 18, 7-34. DOI: 10.1111/j.13652486.2011.02543.x

Högberg, P., 2012 What is the quantitative relation between nitrogen deposition and forest carbon sequestration? Glob. Change Biol. 18, 1-2. DOI: 10.1111/j.1365-2486.2011.02553.x

Hubbard, R.M., Vose, J.M., Clinton, B.D., Elliott, K.J., Knoepp, J.D., 2004. Stand restoration burning in oak-pine forests in the southern Appalachians: effects on aboveground biomass and carbon and nitrogen cycling. Forest Ecol. Manage. 190, 311-321. DOI: $10.1016 /$ j.foreco.2003.10.021

Hyvönen, R., Persson, T., Andersson, S., Olsson, B., Ågren, G.I., Linder, S., 2008. Impact of long-term nitrogen addition on carbon stocks in trees and soils in northern Europe. Biogeochem. 89, 121-137. DOI: doi.org/10.1007/s10533-007-9121-3

IUSS Working Group WRB, 2015. World Reference Base for Soil Resources 2014, update 2015. International soil classification system for naming soils and creating legends for soil maps. World Soil Resources Reports 106. FAO, Rome, Italy.

Jandl, R., Lindner, M., Vesterdal, L., Bauwens, B., Baritz, R., Hagedorn, F., Johnson, D.W., Minkkinen, K., Byrne, K.A., 2007. How strongly can forest management influence soil carbon sequestration? Geoderma 137, 253-268. DOI: 10.1016/j.geoderma.2006.09.003

Jobbágy, E.G., Jackson, R.B., 2000. The vertical distribution of soil organic carbon and its relation to climate and vegetation. Ecol. Appl. 10, 423-436. DOI: 10.1890/10510761(2000)010[0423:TVDOSO]2.0.CO;2 
Johnson, D.W., Curtis, P.S., 2001. Effects of forest management on soil C and N storage: meta analysis. Forest Ecol. Manage. 140, 227-238. DOI: 10.1016/S0378-1127(00)00282-6

Karhu, K., Auffret, M.D., Dungait, J.A.J., Hopkins, D.W., Prosser, J.I., Singh, B.K., Subke, J.A., Wookey, P.A., Agren, G.I., Sebastia, M.-T., Gouriveau, F., Bergkvist, G., Meir, P., Nottingham, A.T., Salinas, N., Hartley, I.P., 2014. Temperature sensitivity of soil respiration rates enhanced by microbial community response. Nature 513, 81-84. DOI: $10.1038 /$ nature 13604

Knicker, H., 2007. How does fire affect the nature and stability of soil organic nitrogen and carbon? A review. Biogeochem. 85, 91-118. DOI: 10.1007/s10533-007-9104-4

Köster, E., Köster, K., Berninger, F., Pumpanen, J., 2015. Carbon dioxide, methane and nitrous oxide fluxes from podzols of a fire chronosequence in the boreal forests in Värriö, Finnish Lapland. Geoderma Regional 5, 181-187. DOI: 10.1016/j.geodrs.2015.07.001

Köster, K., Berninger, F., Heinonsalo, J., Linden, A., Köster, E., Ilvesniemi, H., Pumpanen, J., 2016b. The long-term impact of low-intensity surface fires on litter decomposition and enzyme activities in boreal coniferous forests. Int. J. Wildland Fire 25, 213-223. DOI: 10.1071/WF14217_CO

Köster, K., Berninger, F., Lindén, A., Köster, E., Pumpanen, J., 2014. Recovery in fungal biomass is related to decrease in soil organic matter turnover time in a boreal fire chronosequence. Geoderma 235-236, 74-82. DOI: 10.1016/j.geoderma.2014.07.001

Köster, K., Köster, E., Orumaa, A., Parro, K., Jõgiste, K., Berninger, F., Pumpanen, J., Metslaid, M., 2016a. How time since forest fire affects stand structure, soil physical-chemical properties and soil $\mathrm{CO}_{2}$ efflux in hemiboreal Scots pine forest fire chronosequence? Forests 7, 201. DOI: $10.3390 / \mathrm{f} 7090201$

Köster, K., Püttsepp, Ü., Pumpanen, J., 2011. Comparison of soil $\mathrm{CO}_{2}$ flux between uncleared and cleared windthrow areas in Estonia and Latvia. Forest Ecol. Manage. 262, 65-70. DOI: $10.1016 /$ j.foreco.2010.09.023 
Köster, K., Voolma, K., Jõgiste, K., Metslaid, M., Laarmann, D., 2009. Assessment of tree mortality after windthrow using photo-derived data. Ann. Bot. Fenn. 46, 291-298. DOI: $10.5735 / 085.046 .0405$

Lõhmus, E., 2004. Estonian forest site types. Second Edition. Loodusfoto, Tartu. [In Estonian].

López-Serrano, F.R., Rubio, E., Dadi, T., Moya, D., Andrés-Abellán, M., García-Morote, F.A, Miettinen, H., Martínez-García, E., 2016. Influences of recovery from wildfire and thinning on soil respiration of a Mediterranean mixed forest. Sci. Tot. Environ. 573, 1217--1231. DOI:10.1016/j.scitotenv.2016.03.242

Luo, Y., Zhou, X., 2006. Soil respiration and the environment. Elsevier, USA.

Lytle, D.E., Cronan, C.S., 1998. Comparative soil $\mathrm{CO}_{2}$, evolution, litter decay, and root dynamics in clearcut and uncut spruce-fir forest. Forest Ecol. Manage. 103, 121-128. DOI: $10.1016 / \mathrm{S} 0378-1127(97) 00182-5$

Nave, L.E., Vance, E.D., Swanston, C.W., Curtis, P.S., 2011. Fire effects on temperate forest soil C and N storage. Ecol Appl. 21, 1189-1201. DOI: 10.1890/10-0660.1

Palviainen, M., Pumpanen, J., Berninger, F., Ritala, K., Duan, B., Heinonsalo, J., Sun, H., Köster, E., Köster, K., 2017. Nitrogen balance along a northern boreal forest fire chronosequence. PLoS ONE 12, e0174720. DOI: 10.1371/journal.pone.0174720

Pan, Y., Birdsey, R.A., Fang, J., Houghton, R., Kauppi, P.E., Kurz, W.A., Phillips, O.L., Shvidenko, A., Lewis, S.L., Canadell, J.G., 2011. A large and persistent carbon sink in the world's forests. Science 333, 988-993. DOI: 10.1126/science.1201609

Parro, K., Köster, K., Jõgiste, K., Vodde, F., 2009. Vegetation dynamics in a fire damaged forest area: the response of major ground vegetation species. Balt. For. 15, 206-215.

Parro, K., Metslaid, M., Renel, G., Sims, A., Stanturf, J.A., Jõgiste, K., Köster, K., 2015. Impact of post-fire management on forest regeneration in a managed hemiboreal forest, Estonia. Can. J. For. Res. 45, 1192-1197. DOI: 10.1139/cjfr-2014-0514 
Poirier, V., Paré, D., Boiffin, J., Munson, A.D., 2014. Combined influence of fire and salvage logging on carbon and nitrogen storage in boreal forest soil profiles. Forest Ecol. Manage. 326, 133-141. DOI: 10.1016/j.foreco.2014.04.021

R Core Team, 2017. R: A language and environment for statistical computing. R Foundation for Statistical Computing, Vienna, Austria. URL https:/www.R-project.org/.

Raich, J.W., Tufekcioglu, A., 2000. Vegetation and soil respiration: Correlation and controls. Biogeochem. 48, 71-90. DOI: 10.1023/a:1006112000616

Raich, J.W., Schelesinger, W.H., 1992. The global carbon dioxide flux in soil respiration and its relationship to vegetation and climate. Tellus B 44, 81-99. DOI: 10.1034/j.1600-0889.1992.t01$1-00001 . x$

Saha, S., Catenazzi, A., Menges, E.S., 2010. Does time since fire explain plant biomass allocation in the Florida, USA, scrub ecosystem? Fire Ecol. 6, 13-25. DOI: $10.4996 /$ fireecology.0602013

Schlesinger, W.H., Andrews, J.A., 2000. Soil respiration and the global carbon cycle. Biogeochem. 48, 7-20. DOI: 10.1023/A:1006247623877

Seidl, R., Schelhaas, J.M., Rammer, W., Verker, P.J., 2014. Increasing forest disturbances in Europe and their impact on carbon storage. Nat. Clim. Change 4, 806-810. DOI: $10.1038 /$ nclimate2318

Shorohova, E., Kuuluvainen, T., Kangur, A., Jõgiste, K., 2009. Natural stand structures, disturbance regimes and successional dynamics in the Eurasian boreal forests: a review with special reference to Russian studies. Ann. For. Sci. 66, 201p1-201p20. DOI: $10.1051 /$ forest $/ 2008083$

Striegl, R.G., Wickland, K.P., 1998. Effects of a clear-cut harvest on soil respiration in a jack pine- lichen woodland. Can. J. For. Res. 28, 534-539. DOI: 10.1139/x98-023

Sullivan, B.W, Kolb, T.E., Hart, S.C., Kaye, J.P., Hungate, B.A., Dore, S., Montes-Helu, M., 2011. Wildfire reduces carbon dioxide efflux and increases methane uptake in ponderosa pine 
forest soils of the southwestern USA. Biogeochem. 104, 251-265. DOI: 10.1007/s10533-0109499-1

Wang, Y., Amundson, R., Trumbore, S., 1999. The impact of land use change on C turnover in soils. Glob. Biogeochem. Cy. 13, 47-57. DOI: 10.1029/1998GB900005

Wei, X., Shao, M., Gale, W., Li, L., 2014. Global pattern of soil carbon losses due to the conversion of forests to agricultural land. Sci. Rep. 4, 4062. DOI: 10.1038/srep04062

Widén, B., Majdi, H., 2001. Soil $\mathrm{CO}_{2}$ efflux and root respiration at three sites in a mixed pine and spruce forest: seasonal and diurnal variation. Can. J. For. Res. 31, 786-796. DOI: $10.1139 / \mathrm{x} 01-012$

Yermakov, Z., Rothstein, D.E., 2006. Changes in soil carbon and nitrogen cycling along a 72year wildfire chronosequence in Michigan jack pine forests. Oecologia 149, 690-700. DOI: $10.1007 / \mathrm{s} 00442-006-0474-4$ 